\section{$P-149$ 腎細胞癌の長期予後因子としての尿中ネオ}

防衛医科大学校

上床典康、浅野友彦、辻 明、小田島邦男、中島史雄、 早川正道、中村 宏

【目的】ネオプテリンは て刺激された単球/マクロファージ系の産物である。 我々は、觜細胞癌患者でネオプテリン濃度が上昇する ことを報告してきた。今回我々は、それらの患者の7年 のフォローアッフをを、尿中ネオプテリンの長期予後 因子としての有用性について検討を加えたので報告す る。

【対象及び方法】当院で手術を施行された20名の㻉細 胞癌患者を对象として、術前に尿中ネオフフテリン泿度 を高速液体クロマトグラフィーを用いて測定した。平 均観察期間は95か月であり、尿中ネオプテリン懐度と 病理学的諸因子 ( PTNM分類、異型度、腫瘍径、静脈浸 潤、浸洞增殖様式、細胞型) との多変量解析が検討さ れた。

【結果】5年生存率は、尿中ネオプテリン低濃度 (< $200 \mu \mathrm{mol} / \mathrm{mol}$ creatinine) 群で $89 \%(8 / 9)$ で、尿中ネ オプテリン高濃度 ( $\geq 200 \mu \mathrm{mol} / \mathrm{mol}$ creatinine) 群で8 $\%(1 / 11)$ であり、高濃度群が有意に $(\mathrm{p}<0.01)$ 予後 不良であった。多変量解析では、尿中ネオブテリン濃 度とPTNM分類のみが長期予後に関係していた。

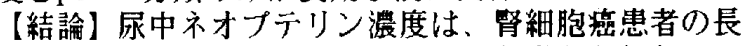
期予捘予測の指標として有用であると考えられた。 \section{$P-151$ マイクロ波凝固によるブタ腎実質变化の組機

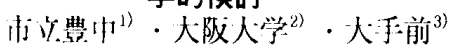

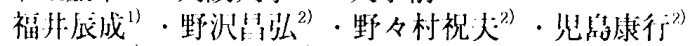

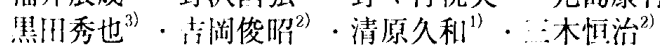 奥山时浐汶}

【月的】マイクロ波凝湖装置（マイクロ夕ーゼ）はすで

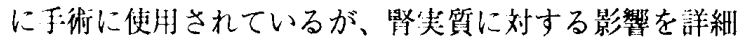
に検部した派告は少ない。今问我々は、照射電力、時閂 を叮変させ、マイクロ波の婜尖質への影響を組織学纳に 検討したので報告する。

【対象と方法】6ケ月龄のブタに対して全身麻醉下に4ケ阿

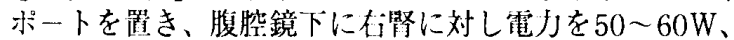
時閂を20４0秒と可変し照射、左照に対し60W、40秒に

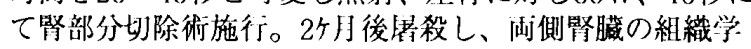
的変化とその範淜を調べた。


リンパ球の浽润等を認め系球体および承細管は変性壊死 に陌り線維化をきたしていた。この組織変性は限局した 変化で、正常域との境界は明暸であった。各電力、冬時 間に㧍ける絊織変性の範囲は $50 \mathrm{~W} 、 20$ 秒で幅 $3 \mathrm{~mm}$ 、深さ $5 \mathrm{~mm}$ 。60W、30秒で幅 $8 \mathrm{~mm}$ 、深さ $5 \mathrm{~mm}$ 。60W、40秒で幅 $12 \mathrm{~mm}$ 、深さ $10 \mathrm{~mm}$ であった。腹腔鏡下腎部分切除術は山 响もなく安全に施行し得たが、残䑍の組織变性はやや㕕 範用に及んでいた。

【考察】マイク口波による腎算の変化は限局しており、 組織変性の範用から60W、30秒照射が適当であると判断 された。今後、マイクロ波㠜做装置を用いて腎阴向を行 わない腹腟鏡ト腎部分切除術が安全に行い得ると考えら れる。

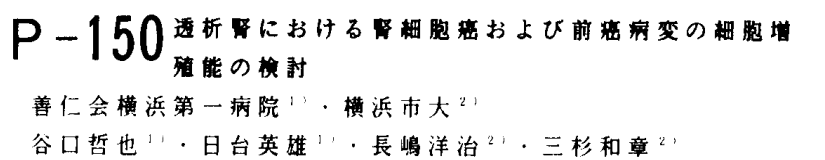

【目的】長期血液透析を受けた患者の堅には堅細胞整が高頻 度に発生する事が知られている。本研究では透析患者督に発

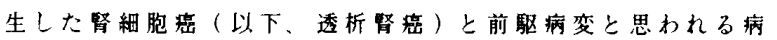
变の增殖能を免疫組化学的に娭討した。

【対象と方法】1990年から96年に当科で督糨のため堅摘を行 つた透析患者督13堅を10\%ホルマリン固定後、全制を行い、型 どおり病理組織本を作製した。病理租樴学的にみられた病 变につき抗增殖細胞核抗原（抗PCNA）抗体（DAKO) 用いた

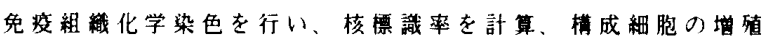
能を㛟討した。

【結果】認められた病变を、1)単栍性胞、2)異型胞、

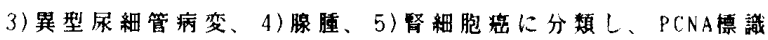
率を計算した。標識事は单純性胞 $0.53 \pm 0.55 \%$ 、翼型胞 $2.23 \pm 1.43 \%$ ，異型尿耕管病变 $6.59 \pm 17.69 \%$ 、腺腫 $4.00 \pm 1.91 \%$ 、

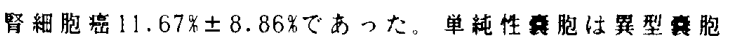
$(p<0.005)$ 、腺腫 $(p<0.0005)$ 、堅細胞筑 $(p<0.0005)$ の標

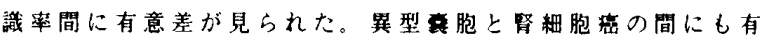
意差を認めた $(\rho<0.05)$ 。

【考察】透析腎虎に合併した前虫病变と思われる病变の增殖 能は、单純性胞、異型胞、腺腫の順に渐次、摽識事の上开 を示し、恵性八の移行を反映すると思われた。型型尿紐管病 变の意義については、更なる㛟討を要する。

(本研究は鉿木泌尿器財団ならびに車両財団上り助成を受けた)

\section{$P-152$ インターフェロン $\alpha$ を中とした集学的

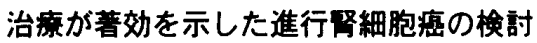

徳島大学"高知市民2屋島総合"爱媛県立中央 "小松島日赤” 村上佳秀 ${ }^{n}$. 金山博臣 ${ }^{1}$. 香川 征 ${ }^{1}$. 藤田次郎 ${ }^{2}$. 福川徳三 $*$ 中島幹夫・桜井紀嗣

【日的】㐴-7エロン $\alpha(\mathrm{INF} \alpha)$ を中とした集学的治療が著 効を示した進行謷細胞癌症例についてその臨床的·病理的 な特徽と有効な INF $\alpha$ 投与方法について検討すること。

【対象と方法】INF $\alpha$ を中しした集学的治療により完全 寛解が得られた進行腎細胞癌症例 7 例(術後再発例 2 例、未 治療進行例 5 例)を対象とした。それぞれ臨末的·病理的な 所見と治療内容、予後について調查した。平均観察期間は INF $\alpha$ 投与開始から 39 ケ月(11〜72 ヶ月)である。【結果】 全例、男性で平均年齢は 54.9 才(42 73才)。再発·転移部位 は肺のみ 3 例、肺と骨 3 例、肺と肺門版節。骨が 1 例であ る。原発巣の病理検査で、細胞型では、clear cell type4 例 mixed type3 例. G1:2 例、G1:3 例、G3:2 例であった。血液 検査で炎症所見のあるものは7例中 2 例であった。CRを得

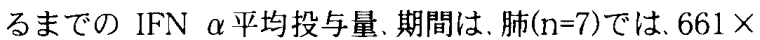
$10^{6}$ 単位、10ケ月、骨 $(\mathrm{n}=4)$ では $1398 \times 10^{6}$ 単位. 32 ケ月を要 した。4例はUFTが併用され 1 例は 5-FU、MMC が投与さ れていた。また，骨転移の1例には TAEが施行された。CR 後の INF $\alpha$ 維持投与は減量例が 2 例、その1例は 18 ケ後 に中止されていた。予後は. 7 例中 5 例が CR 後再発なく生 存。1 例は 14 か月後に脳転移を認めたが放射線治療により CR を得た（減量維持例）。1 例は 59 ケ月後骨に再発を認 めたが生存中である。【結語】INF $\alpha$ が著効を示した症例 は、再発·転移部位は肺、肺門リパ節、骨に限られていた。長 期奏効例を得るためには、継続的な INF $\alpha$ の投与と適切な 集学的補助治療の必要があると考えられた。 